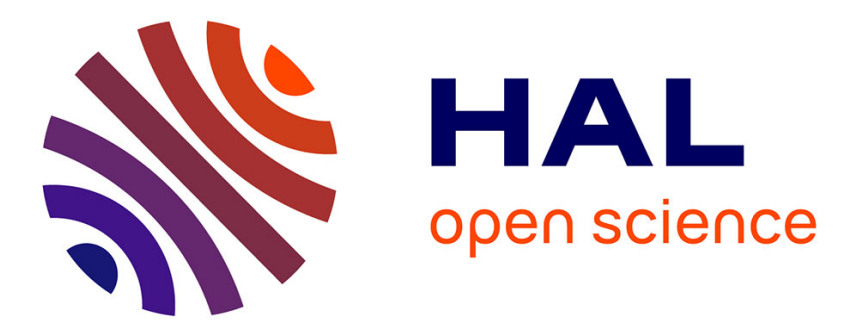

\title{
Feed gas humidity: a vital parameter affecting a cold atmospheric-pressure plasma jet and plasma-treated human skin cells
}

Joern Winter, Kristian Wende, Kai Masur, Sylvain Iséni, Mario Dünnbier, Malte U Hammer, Helena Tresp, Klaus-Dieter Weltmann, Stephan Reuter

\section{To cite this version:}

Joern Winter, Kristian Wende, Kai Masur, Sylvain Iséni, Mario Dünnbier, et al.. Feed gas humidity: a vital parameter affecting a cold atmospheric-pressure plasma jet and plasma-treated human skin cells. Journal of Physics D: Applied Physics, 2013, 46 (29), pp.295401-295401. 10.1088/00223727/46/29/295401. hal-03271692

\section{HAL Id: hal-03271692 https://hal.science/hal-03271692}

Submitted on 26 Jun 2021

HAL is a multi-disciplinary open access archive for the deposit and dissemination of scientific research documents, whether they are published or not. The documents may come from teaching and research institutions in France or abroad, or from public or private research centers.
L'archive ouverte pluridisciplinaire HAL, est destinée au dépôt et à la diffusion de documents scientifiques de niveau recherche, publiés ou non, émanant des établissements d'enseignement et de recherche français ou étrangers, des laboratoires publics ou privés.

$$
\text { Copyright }
$$




\title{
Feed gas humidity: a vital parameter affecting a cold atmospheric-pressure plasma jet and plasma-treated human skin cells
}

\author{
J Winter ${ }^{1,2,3}$, K Wende ${ }^{1,2,3}$, K Masur $^{1,2}, \mathbf{S}$ Iseni $^{1,2}$, M Dünnbier ${ }^{1,2}$, \\ M U Hammer ${ }^{1,2}$, H Tresp ${ }^{1,2}$, K-D Weltmann ${ }^{2}$ and S Reuter ${ }^{1,2}$ \\ ${ }^{1}$ Centre for Innovation Competence plasmatis, Felix-Hausdorff-Str. 2, 17489 Greifswald, Germany \\ ${ }^{2}$ Leibniz Institute for Plasma Science and Technology INP Greifswald e.V., Felix-Hausdorff-Str. 2, 17489 \\ Greifswald, Germany \\ E-mail: winter@inp-greifswald.de and kristian.wende@inp-greifswald.de
}

Received 22 April 2013, in final form 26 May 2013

Published 27 June 2013

\begin{abstract}
In this study, the effect of feed gas humidity on the reactive component generation of an atmospheric-pressure argon plasma jet and its effect on human skin cells are investigated. Feed gas humidity is identified as one key parameter that strongly influences stability and reproducibility of plasma medical studies. The plasma jet is investigated by absorption spectroscopy in the ultraviolet and infrared spectral region for its ozone production depending on the humidity concentration in the feed gas. By optical emission spectroscopy the dependence of present excited plasma species such as hydroxyl radicals, molecular nitrogen, argon and atomic oxygen on the feed gas humidity is investigated. As an interface layer between the plasma jet effluent and the biological cell, a buffer solution is treated and the hydrogen peroxide $\left(\mathrm{H}_{2} \mathrm{O}_{2}\right)$ production is studied with two independent colorimetric assays as a function of humidity admixture to the feed gas. Ultimately, the effect of varying feed gas humidity on the cell viability of indirect plasma treated adherent HaCAT cells is investigated. The highest viability is found for the driest feed gas condition. Furthermore, this work shows answers for the relevance of unwanted — or intended — feed gas humidity in plasma medical experiments and their comparatively large relevance with respect to ambient humidity. The findings will lead to more reproducible experiments in the field of plasma medicine.
\end{abstract}

\section{Introduction}

The past decade has seen the rise of atmospheric-pressure lowtemperature plasmas. These plasmas operated under ambient conditions find a wide range of applications, e.g. in surface treatment of polymers [1-3], treatment of woven fabrics [4] and surface functionalization [5], and also as actuators for the control of air flow in aeronautics [6]. Atmospheric-pressure plasmas are increasingly used for deposition of thin films [7] or generation of carbon nanotubes [8]. Advantages are that large and expensive vacuum equipment can be omitted and high reactive species density can be achieved due to the high density

\footnotetext{
3 These authors contributed equally to this work.
}

under ambient conditions. High focus is set on application of atmospheric-pressure plasmas in the medical sector. In this sector, a large scientific community has evolved investigating applications of wound treatment, biocompatible surfaces, or disinfection, inactivation of pathogens, sterilization of medical equipment as well as the inactivation of bacteria in biofilms, see e.g. [9-12]. The high reactivity at low gas temperatures due to the strong non-equilibrium properties of these plasmas can be utilized to generate a reactive chemistry, usually available only at high temperatures, on temperature-sensitive surfaces such as human skin.

In particular in the medical sector, plasma sources are operated in ambient air, introducing humidity into the active plasma zone. Humidity plays an important role 
in plasma chemical processes since dissociation of water $\left(\mathrm{H}_{2} \mathrm{O}\right)$ opens a wide variety of subsequent plasma chemical reactions [13]. This is especially true for atmosphericpressure plasmas operated in humid ambient air but also for noble gas driven atmospheric-pressure plasma jets [14-16]. In the case of plasma jets, humidity is either introduced directly into the working gas as impurity or diffuses into the effluent when the jet is operated in a humid environment. In biomedical applications, changing humidity conditions not only has an influence on the plasma but also on the plasmatreated biological targets, such as cells or cell structures [17]. The products originating from the water reaction pathways, for example hydroxyl $(\mathrm{OH})$, atomic oxygen $(\mathrm{O})$ and hydrogen peroxide $\left(\mathrm{H}_{2} \mathrm{O}_{2}\right)$ are potent to generate oxidative stress in biological samples. This is already known from decontamination experiments, where bacteria were plasmatreated under different humidity settings [18]. For eukaryotic cells relevant for plasma medicine (e.g. human skin cells) no such data exist. Hence, the focus of this work is not only the investigation of feed gas humidity influence on the reactive component generation of an atmosphericpressure argon plasma jet by optical emission and absorption spectroscopy but also the observation of in vitro human keratinocyte behaviour to indirect plasma treatment. It is shown in this work that increasing feed gas humidity leads to a significant viability decrease in the investigated cell line. In order to get a first glimpse into the governing mechanisms, the $\mathrm{H}_{2} \mathrm{O}_{2}$ concentration in the liquid growth medium is also monitored. The increase in $\mathrm{H}_{2} \mathrm{O}_{2}$ concentration with feed gas humidity suggests a correlation between $\mathrm{H}_{2} \mathrm{O}_{2}$ and cell viability.

In addition to the fundamental research aspects, it is shown that gas supply tubes made of polyurethane (PUR) are a major source of feed gas humidity and must be considered from the practical point of view. Moreover, the large relevance of feed gas humidity with respect to ambient humidity is emphasized in this paper.

\section{Experimental setup}

\subsection{Plasma jet}

The investigated plasma source is a cold atmospheric-pressure plasma jet (kinpen, neoplas GmbH, Greifswald, Germany). It consists of a centred rod electrode inside a ceramic capillary and a grounded ring electrode $[19,20]$. When a sinusoidal voltage signal of $2-6 \mathrm{kV}_{\mathrm{pp}}$ with a frequency of about $1 \mathrm{MHz}$ is applied to the centred electrode, plasma is ignited within the core region of the jet. Also an up to $10 \mathrm{~mm}$ long effluent becomes visible after ignition. The working gas is argon ( $\mathrm{Ar}$ purity $99.999 \%$ ) with a gas flow rate of 3 standard litres per minute (slm). Furthermore, the humidity concentration of the feed gas is changed with the setup described in detail in section 2.3 .

\subsection{Humidity measurements in gas supply tubes}

Feed gas tubes made of PUR can absorb a significant amount of water when they are exposed to a humid environment. In

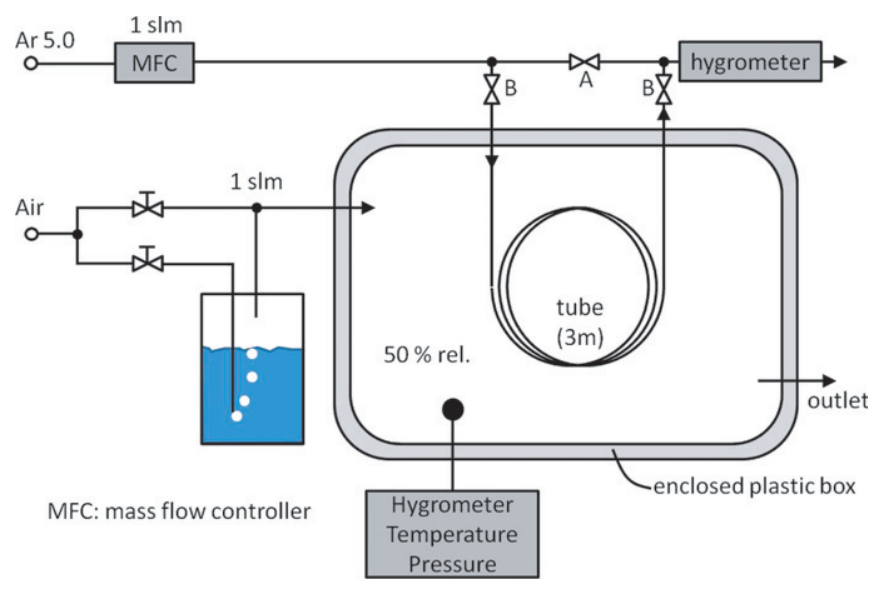

Figure 1. Experimental setup for measuring the water concentration that originates from a previously humidified tube.

operation, dry gas from the gas bottle becomes humidified while streaming through such previously humidified feed gas tubes. Hence, a significant number of water molecules are transported by the feed gas into the core plasma region of the investigated plasma jet. In order to determine the number of water molecules that originate from feed gas tubes the experimental setup in figure 1 was used. A $3 \mathrm{~m}$ long PUR tube (Norgren, Germany) with inner and outer diameters of $4 \mathrm{~mm}$ and $6 \mathrm{~mm}$, respectively, was enclosed by a plastic box. The air atmosphere inside the box was set to a relative humidity level of $50 \%$ (corresponds to an absolute $\mathrm{H}_{2} \mathrm{O}$ concentration of $1.4 \%$ ) by means of a humidified constant air flow rate of $1 \mathrm{slm}$. The measurement procedure had three phases. In the first phase dry argon gas at a flow rate of 1 slm was led through the $3 \mathrm{~m}$ tube for $12 \mathrm{~h}$. Therefore, valves B were opened and valve A was closed. After this drying phase the second phase began in which valves B were closed and valve A was opened. Now, the dried argon filled tube was exposed to the humidified atmosphere in the box for another $12 \mathrm{~h}$. Meanwhile the argon gas kept flowing through valve A. This provides unchanged dry conditions for the supply tubes. In the third phase, valves B were opened and valve A was closed again, so that dry argon gas flew through the humidified tube. The gas humidity was measured over time with a chilled mirror dew point hygrometer (DewMaster, EdgeTech, USA) with an uncertainty of about $2 \%$. The humidity concentration detection limit of this hygrometer was 20 parts per million (ppm). For comparison, a $3 \mathrm{~m}$ long stainless steel pipe with the same dimensions as the PUR tube was analysed with the same procedure.

\subsection{Feed gas humidification and optical emission spectroscopy}

To investigate the effect feed gas humidity has on emission spectra and on biological samples the humidity of the feed gas was controlled. Due to the difficulty in adjusting humidification by gas tubes, a controlled feed gas humidification was performed with a bubbler setup. Dry argon gas was split into two channels, a main gas channel and a channel which was guided through a water reservoir. 


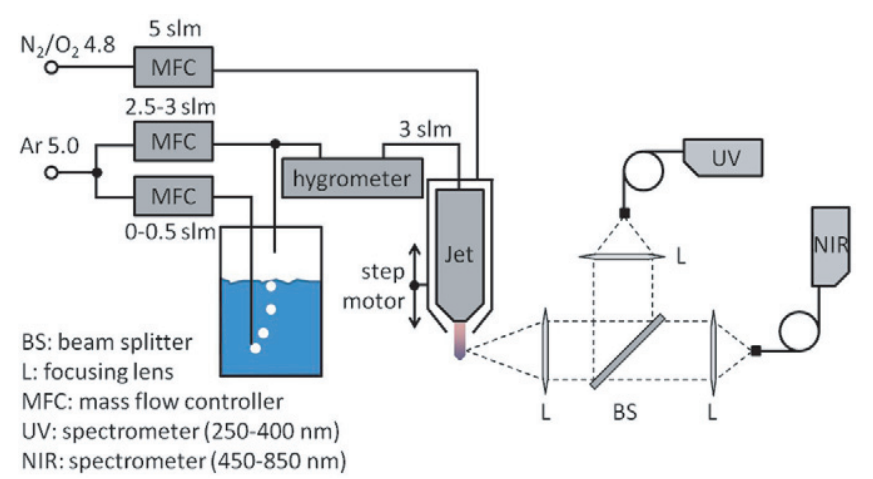

Figure 2. Scheme of the optical emission spectroscopy setup and of gas humidification.

Behind the bubbler, both argon gas streams were mixed and the resulting humidity was analysed by the chilled mirror dew point hygrometer already described in section 2.2. Afterwards the humidified feed gas was led into the plasma jet. By changing the argon flow rate through the bubbler in the range $0-0.5 \mathrm{slm}$ the feed gas humidity was precisely adjusted between 20 and $1300 \mathrm{ppm}$. To provide a constant total argon flow rate of $3 \mathrm{slm}$ the dry gas channel flow rate was appropriately reduced.

A sketch of the humidification setup in combination with the optical emission spectroscopy (OES) setup is displayed in figure 2. The OES was performed using a UV and a NIR sensitive spectrometer (AvaSpec-2048-USB2, Avantes) with a spectral resolution of $0.7 \mathrm{~nm}$, respectively. The axially resolved emission spectra with a spatial resolution of $0.5 \mathrm{~mm}$ were obtained for different humidity concentrations. Particularly four spectral regions were evaluated in this work corresponding to the emission of argon atoms (Ar 4p4s, 695-698 nm), hydroxyl radicals $\left(\mathrm{OH} A^{2} \Sigma^{+} \rightarrow X^{2} \Pi\right.$, $305-313 \mathrm{~nm})$, nitrogen molecules $\left(\mathrm{N}_{2} C^{3} \Pi_{\mathrm{u}} \rightarrow B^{3} \Pi_{\mathrm{g}}\right.$, $330-338 \mathrm{~nm})$ and atomic oxygen (O $3 \mathrm{p}-3 \mathrm{~s}, 775-778 \mathrm{~nm})$. Integrating the respective emission intensities for different axial positions $(0-10 \mathrm{~mm}$, step size: $0.5 \mathrm{~mm})$ and different feed gas humidity concentrations over the given spectral ranges and normalizing to the maximal value yields an emission intensity map for each species.

Furthermore, the plasma jet was equipped with a shielding device that enables the shielding of the effluent plasma from ambient species [21]. In order to investigate whether feed gas humidity differentially influences the plasma composition than ambient humidity two experiments were performed using this shielded jet. Firstly, dry air as shielding gas and humidified argon with a humidity concentration of $490 \mathrm{ppm}$ as feed gas were used. In this situation, the humidity concentration in the effluent is only determined by the feed gas humidity. Secondly, the opposite situation, namely humidified shielding gas with a humidity concentration of $20500 \mathrm{ppm}$ (corresponds to a relative humidity level of $72 \%$ ) and dry feed gas, was investigated. As a measure for the impact of both situations the excited $\mathrm{OH}$ emission was analysed with the setup explained above.

\subsection{Ozone net production rate}

The ozone net production rate of the investigated plasma jet operated with $3 \mathrm{slm}$ argon plus $1 \%$ oxygen was determined for different feed gas humidity concentrations using UV and IR absorption spectroscopy techniques identical to the setups reported in $[20,22]$. For a comparison of both techniques, the measurement setup-independent net production rate was calculated, considering the velocity profile of the gas for UV absorption and the total flow rate for IR absorption. Details of the production rate calculation are also given in the two papers already mentioned above. The humidification of the feed gas was performed with the bubbler setup described in section 2.3.

\subsection{Plasma treatment and hydrogen peroxide determination in RPMI solution}

The plasma treatment was performed in a polystyrene Petri dish (53 mm diameter TPP, Trasdingen, $\mathrm{CH}$ ) filled with $5 \mathrm{ml}$ complete cell growth medium (Roswell Park Memorial Institute $1640-$ RPMI $+8 \%$ foetal calf serum $+1 \%$ penicillin/streptomycin solution). In order to treat the liquid at different positions the plasma jet was mounted on an $x y$-table, and the plasma jet effluent was moved in a meandering pattern over the liquid for a constant treatment time of $40 \mathrm{~s}$. The distance between the nozzle and the liquid surface was set to $9 \mathrm{~mm}$. The $\mathrm{H}_{2} \mathrm{O}_{2}$ concentration of the treated liquid was analysed using commercial $\mathrm{H}_{2} \mathrm{O}_{2}$ test stripes (Merckoquant 110011, Merck) and via an Amplex Red homogeneous assay. Aliquots of $50 \mu \mathrm{l}$ (Amplex Red assay) and $30 \mu \mathrm{l}$ (test stripes) were taken immediately after $40 \mathrm{~s}$ plasma treatment time. The experiment was repeated three times for each humidity setting.

The $\mathrm{H}_{2} \mathrm{O}_{2}$ test stripes were read out by a digital microscope camera (Conrad, Germany) in order to analyse their colour value. A calibration procedure was conducted prior to the experiments. Therefore, 13 different $\mathrm{H}_{2} \mathrm{O}_{2}$ concentrations from 0 to $6 \mathrm{mg} \mathrm{l}^{-1}$ were produced by diluting $10 \mathrm{M} \mathrm{H}_{2} \mathrm{O}_{2}$ stock solution (340 $\mathrm{gl}^{-1}$, Merck KGAA) in RPMI and $\mathrm{H}_{2} \mathrm{O}$. The sum of the colour values of the red and green camera channel for different $\mathrm{H}_{2} \mathrm{O}_{2}$ concentrations is plotted in figure 3 . Regardless of whether the calibration was performed in RPMI or $\mathrm{H}_{2} \mathrm{O}$ almost the same linear calibration characteristic was observed. The linear approximation of the data allows the determination of an unknown $\mathrm{H}_{2} \mathrm{O}_{2}$ concentration by measuring the colour change of a test stripe.

Another method to detect $\mathrm{H}_{2} \mathrm{O}_{2}$ in liquid is the usage of a homogeneous assay (Amplex Red Hydrogen Peroxide/Peroxidase Assay Kit, Invitrogen, Ltd). The kit uses the Amplex Red reagent (10-acetyl-3,7-dihydroxyphenoxazine). After $40 \mathrm{~s}$ plasma treatment time $50 \mu \mathrm{l}$ of the treated solution were transferred into a well of a 96-well plate. The well already contains a volume of $50 \mu \mathrm{l}$ reaction buffer solution according to the protocol provided by the company. Furthermore, a standard curve with known $\mathrm{H}_{2} \mathrm{O}_{2}$ concentrations was also prepared in the 96-well plate. The absorption and fluorescence signals at wavelengths of $560 \mathrm{~nm}$ and $590 \mathrm{~nm}$, respectively, were obtained by means of a multiplate reader (Tecan infinite M200, Tecan Group Ltd, Switzerland). By comparing the results of the standard curve with the samples taken at different 


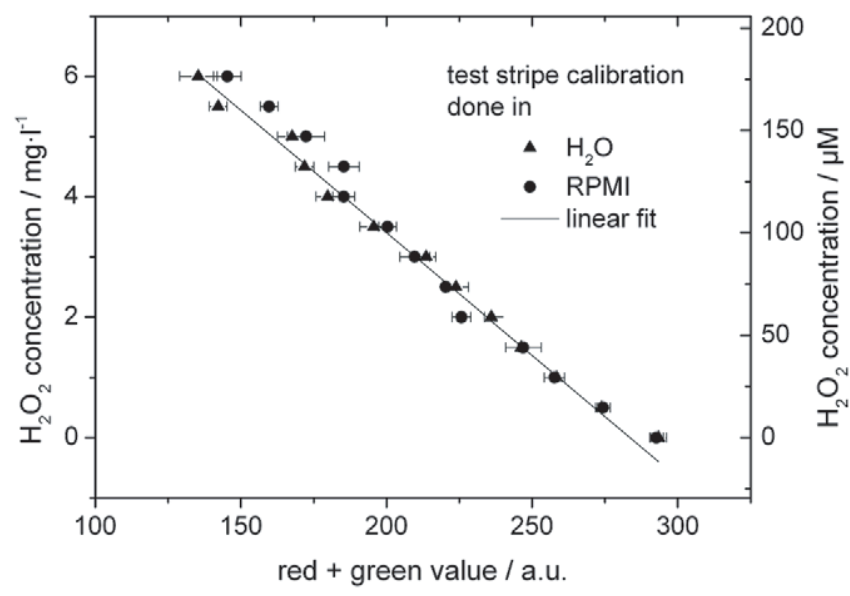

Figure 3. $\mathrm{H}_{2} \mathrm{O}_{2}$ test stripe calibration curve.

feed gas humidity levels the plasma treatment induced $\mathrm{H}_{2} \mathrm{O}_{2}$ concentrations after $40 \mathrm{~s}$ treatment time were determined. By comparison with the test stripe method the Amplex Red assay is more sophisticated but also more sensitive. The $\mathrm{H}_{2} \mathrm{O}_{2}$ test stripe lower detection limit is about $0.5 \mathrm{mg}^{-1}$, whereas a significant lower detection limit of $0.2 \mathrm{ng}^{-1}$ is reported for the Amplex Red assay [23].

\subsection{Cell viability assay}

The viability of adherent human keratinocytes (HaCaT cells) was determined using the conversion of fluorescence dye resazurin by metabolic active cells into the highly fluorescent resorufin. Details of this assay are given in [24]. The cells were cultivated in the same medium that was used for the $\mathrm{H}_{2} \mathrm{O}_{2}$ measurements.

After $40 \mathrm{~s}$ plasma treatment of $5 \mathrm{ml}$ RPMI solution under the equivalent conditions as described for the $\mathrm{H}_{2} \mathrm{O}_{2}$ measurements, the plasma-treated medium was immediately transferred into one row of wells of the cell culture plate and serially diluted with complete medium immediately (six parallel wells per treatment time) to obtain different treatment time equivalents. Analogous to the procedure described in [24] the cells were cultivated for a further $71 \mathrm{~h}$ and fluorescence intensity after resazurin addition $(100 \mu \mathrm{M}$ resazurin in complete RPMI w/o phenol red) was analysed by a Tecan M200 multiplate reader after $1 \mathrm{~h}$ of incubation. As a measure of viability the $50 \%$ inhibition value was determined for every investigated feed gas humidity level (example for 20 ppm see figure 4).

\section{Results and discussion}

\subsection{Humidity originating from feed gas tubes}

The humidity concentration in dependence on the gas tube flushing time is displayed in figure 5 for the two investigated materials, namely PUR and stainless steel. For the PUR tube an initial humidity concentration of more than $1000 \mathrm{ppm}$ depicts a high porosity and storage capacity of this material for water molecules. With increasing flushing time a drying of the inner

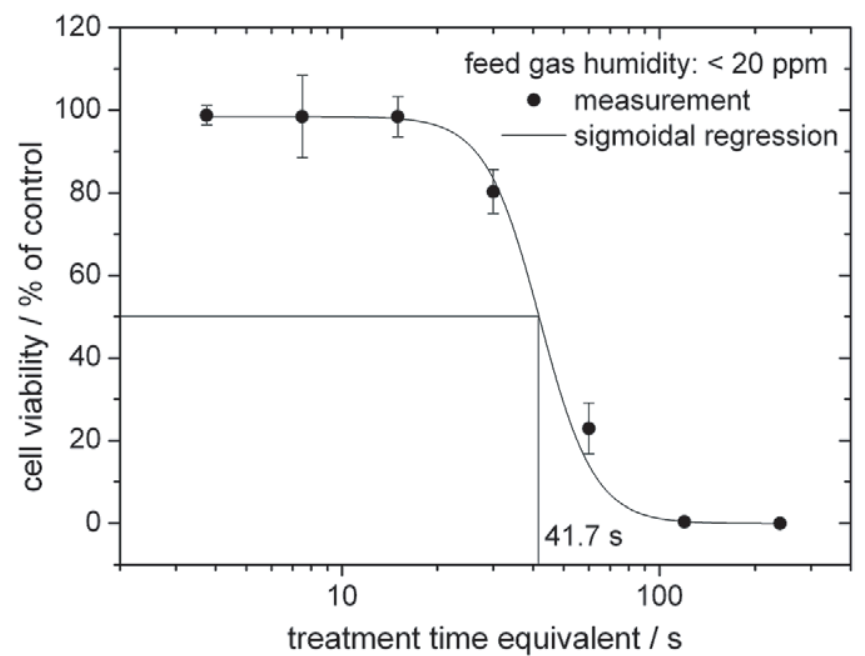

Figure 4. Cell viability in dependence on the treatment time equivalent for a feed gas humidity level of below $20 \mathrm{ppm}$. The $50 \%$ value was determined via sigmoidal regression (here $41.7 \mathrm{~s}$ treatment time equivalent).

tube surface occurs. However, it takes more than $3 \mathrm{~h}$ of flushing time to decrease the feed gas humidity concentration of a $3 \mathrm{~m}$ long PUR tube under a level of $70 \mathrm{ppm}$, which from a practical point of view can be considered as dry. In contrast, the initial feed gas humidity concentration for the investigated metal tube of the same length is by one order of magnitude lower than for the polymeric tube. Already after a couple of minutes the humidity concentration is significantly lower than $70 \mathrm{ppm}$. A consequence of these findings is that not only dry but also stable humidity conditions in the feed gas can be easily achieved with metal tubes. However, metal tubes are expensive and by far not as practical as polymeric tubes. Thus, in the majority of cases, the usage of polymeric tubes can possibly not be avoided totally. In experiments that require stable humidity concentrations it is therefore important to consider polymeric feed gas tubes as a significant source of humidity. From a practical point of view the length of these tubes should be limited as far as possible in order to reduce the drying phase before the experiments.

\subsection{Optical emission spectroscopy}

The emission spectrum of the jet effluent at an axial position of $4 \mathrm{~mm}$ and for a feed gas humidity concentration of $350 \mathrm{ppm}$ shows several emission bands and atomic lines in the ultraviolet (figure 6) and near infrared spectral range (figure 7). In the UV spectral range, emission bands of $\mathrm{OH}\left(A^{2} \Sigma^{+}-X^{2} \Pi\right)$ and $\mathrm{N}_{2}\left(C^{3} \Pi_{\mathrm{u}}-B^{3} \Pi_{\mathrm{g}}\right)$ originate from the dissociation of feed gas water molecules and the diffusion of ambient nitrogen into the effluent [21, 24].

In the NIR spectral range, a set of atomic argon lines $\operatorname{Ar}(4 \mathrm{p}-4 \mathrm{~s})$ and the triplet of atomic oxygen lines $\mathrm{O}\left(3 \mathrm{p}^{5} \mathrm{P}-\right.$ $3 \mathrm{~s}^{5} \mathrm{~S}$ ) around $777 \mathrm{~nm}$ were measured. The atomic oxygen can either originate from water dissociation alongside with the formation of hydrogen molecules or be generated by dissociation of ambient molecular oxygen that diffuses into the effluent. Focusing on the effluent no lines of atomic hydrogen 


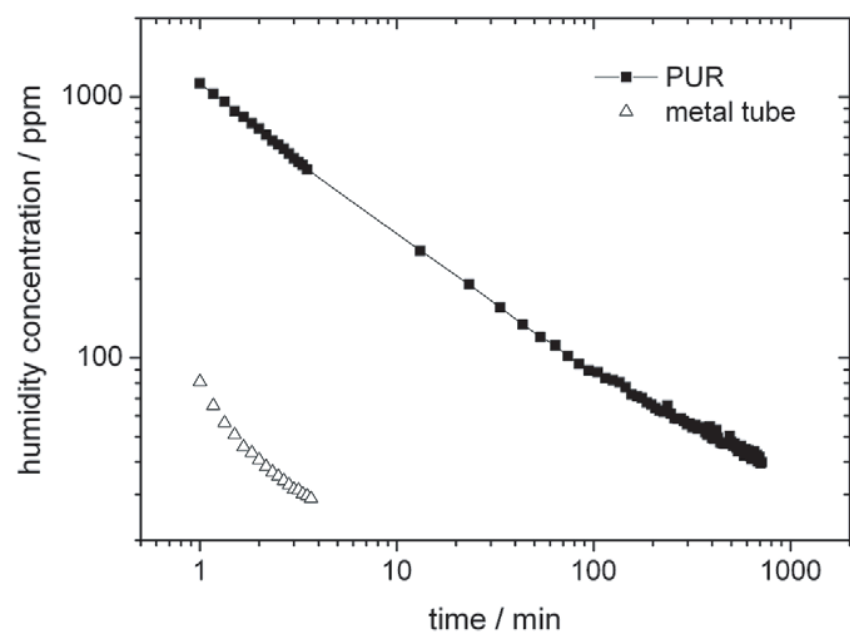

Figure 5. Humidity concentration in argon feed gas (flow rate: $1 \mathrm{slm}$ ) in dependence on the flushing time through a $3 \mathrm{~m}$ long tube made of either PUR or stainless steel.

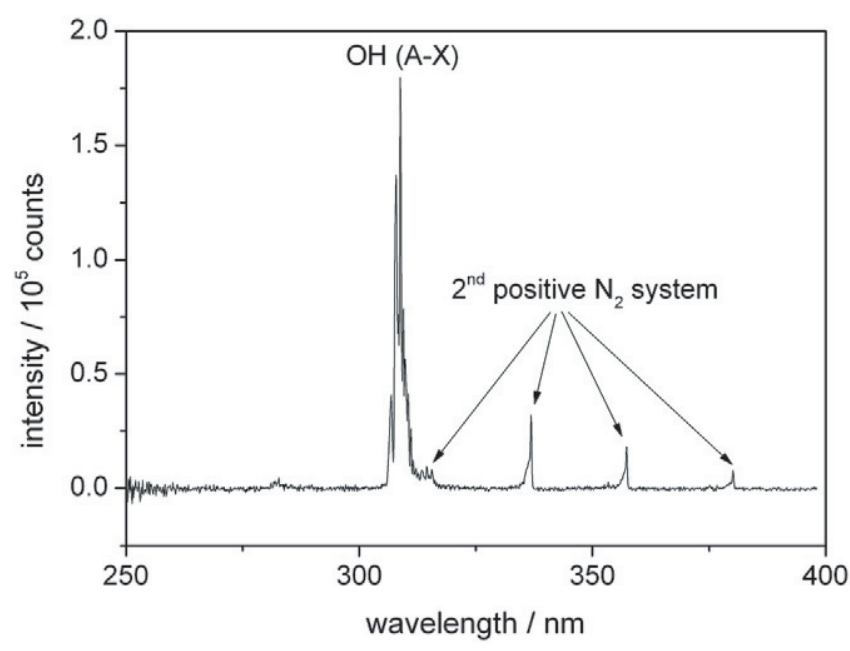

Figure 6. UV emission spectrum at an axial position of $4 \mathrm{~mm}$ and for a feed gas humidity concentration of $350 \mathrm{ppm}$.

were found. However, end-on OES measurements (not shown here) reveal the presence of atomic hydrogen $\left(\mathrm{H}_{\alpha}\right.$ and $\mathrm{H}_{\beta}$ lines $)$ in the active plasma zone and thus confirm water dissociation at least in that region.

Since humidity concentration variation changes not only the plasma chemistry but also the excitation conditions, a strong influence on the emission intensity of the investigated species is expected. Furthermore, the density of molecular oxygen and nitrogen varies with axial distance whereby a spatial dependence on the emission intensity also occurs. Hence, the integral emission intensity was evaluated for both parameters. The result is presented in figure 8 for the four discussed species $\mathrm{Ar}, \mathrm{OH}, \mathrm{N}_{2}$ and $\mathrm{O}$. Every emission intensity map is normalized to the maximum value, respectively. The dots in the contour plot give the parameter settings at which the measurements were actually conducted. The intermediate values were calculated by $2 \mathrm{D}$ linear interpolation.

It has to be mentioned that careful interpretation is necessary when evaluating OES data. Since emission intensities in figure 8 are integrated over band structures

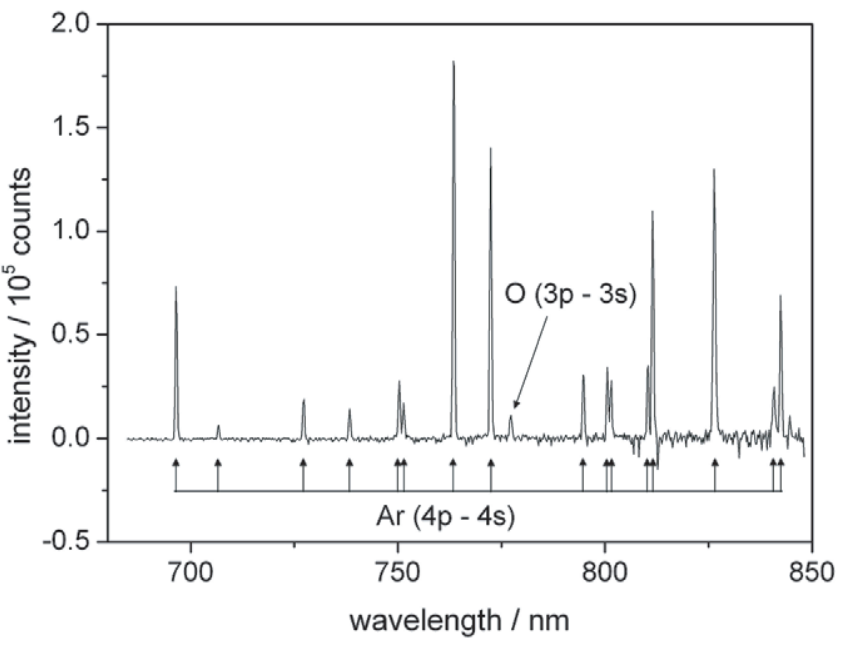

Figure 7. NIR emission spectrum at an axial position of $4 \mathrm{~mm}$ and for a feed gas humidity concentration of $350 \mathrm{ppm}$.

$\left(\mathrm{OH}, \mathrm{N}_{2}\right)$ and over atomic lines (Ar, O) their resulting intensities cannot be directly compared. However, by evaluating the respective dependences on the axial position and on the humidity concentration valuable information is obtained despite the lack of quantitative comparability.

With increasing humidity concentration in the feed gas the emission of argon and oxygen lines and the band emission of nitrogen decrease. Two different effects are responsible for this finding. Firstly, with increasing humidity concentration in the feed gas quenching of excited states by water molecules becomes more likely [25]. This is illustrated by the quenching rate coefficients and decay rates given in table 1 . For a humidity concentration of $1000 \mathrm{ppm}$ (corresponding to a $\mathrm{H}_{2} \mathrm{O}$ density of $2.47 \times 10^{16} \mathrm{~cm}^{-3}$ at atmospheric pressure), the decay rate of $\mathrm{N}_{2}\left(C^{3} \Pi_{\mathrm{u}}, v=0\right)$ due to quenching by water molecules is in the same order of magnitude as the radiative decay rate and therefore plays an important role for depopulating the excited nitrogen state. Unfortunately, no data on the quenching rate coefficients by water vapour were found in the literature for the $\mathrm{O}\left(3 \mathrm{p}^{5} \mathrm{P}\right)$ and $\operatorname{Ar}\left(2 \mathrm{p}_{2}\right)$ states. However, assuming that the unknown coefficients are roughly comparable to the known quenching rate coefficients of $\mathrm{O}\left(3 \mathrm{p}^{3} \mathrm{P}\right)$ and $\operatorname{Ar}\left(1 \mathrm{~s}_{5}\right)$ water molecules also play a major role in the depopulation of these excited atomic states.

Secondly, it is known that the admixture of molecular gases leads to a reduction in electron temperature [36] and therefore affects the formation of photons and energetic species such as argon metastables $\operatorname{Ar}\left(1 \mathrm{~s}_{5}\right)$ in the active plasma zone. These photons and also the metastable argon atoms with energies of $11.55 \mathrm{eV}$ and a lifetime on the order of ten microseconds transport energy from the active plasma zone into the effluent and induce dissociation and excitation processes of other species [37,38]. If, for instance, the formation of Ar metastables is impeded by water molecules, Ar metastable induced excitation processes in the effluent are also impeded and the emission intensity deceases. Hence, the emission intensity of excited $\mathrm{Ar}, \mathrm{O}$ and $\mathrm{N}_{2}$ decreases with water vapour admixture.

The emission of $\mathrm{OH}\left(A^{2} \Sigma^{+}, v=0\right)$ behaves differently from that of the other species. For small water admixtures 

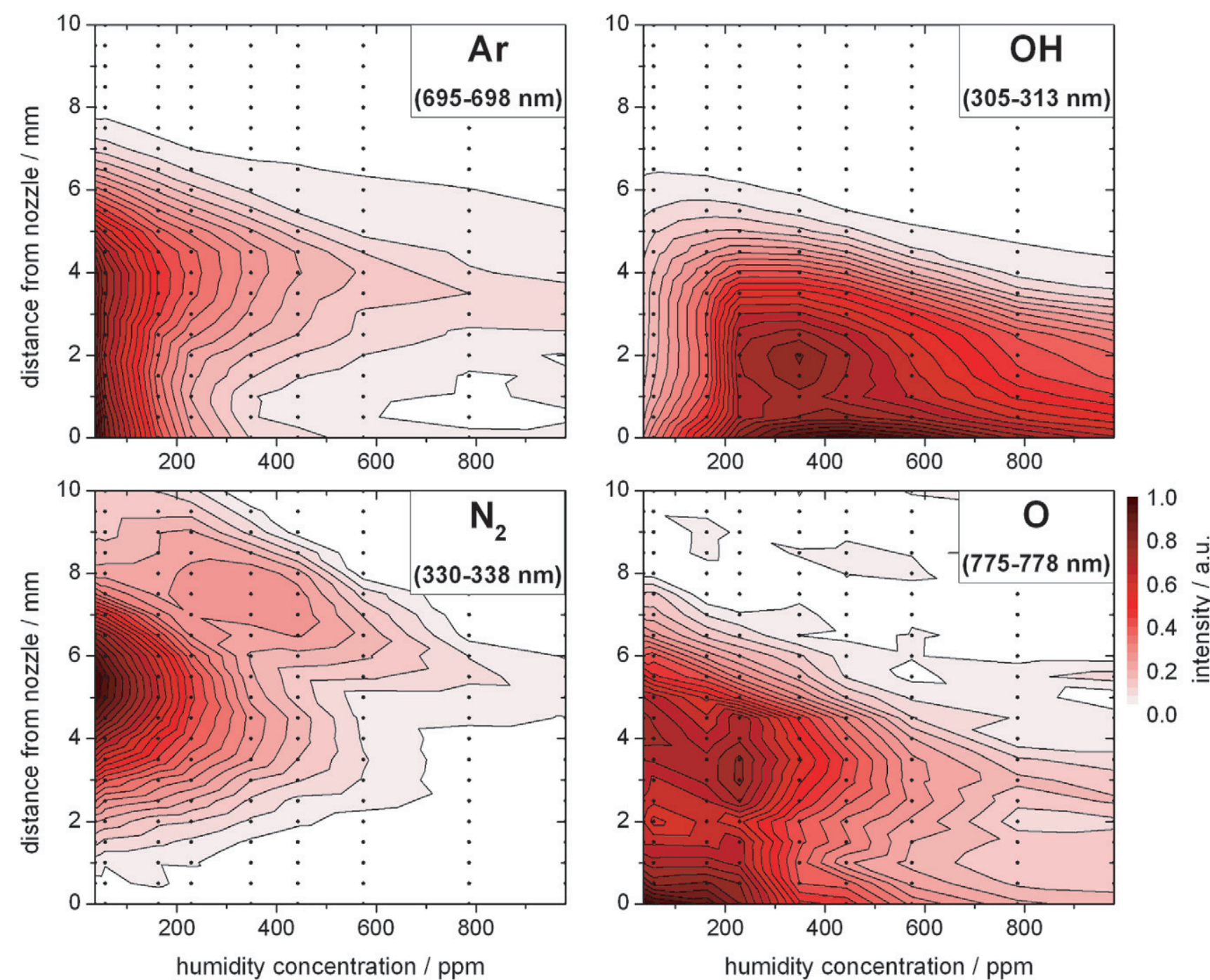

Figure 8. Integrated emission signals originating from $\mathrm{Ar}, \mathrm{OH}, \mathrm{N}_{2}$ and $\mathrm{O}$ in dependence on the axial distance and feed gas humidity concentration. The dots in the contour plot give the position and humidity concentration where the measurements were conducted. The intermediate values were obtained by linear interpolation. Due to different integration intervals (wavelength integration ranges are given in parentheses below the species label), intensities of different species cannot be directly compared.

an increase in $\mathrm{OH}$ emission is observed up to a humidity concentration level of about $400 \mathrm{ppm}$. This is similar to the results of Nikiforov et al on a DBD argon jet, who found an emission maximum of $\mathrm{OH}\left(A^{2} \Sigma^{+}, v=0\right)$ at a water vapour concentration of $350 \mathrm{ppm}$. Presumably, the $\mathrm{OH}$ density increases with rising $\mathrm{H}_{2} \mathrm{O}$ admixture due to direct dissociation of water molecules by electrons. This effect would lead to a stronger emission signal provided that excitation mechanisms do not change significantly by small $\mathrm{H}_{2} \mathrm{O}$ admixtures. However, when increasing the humidity concentration beyond $400 \mathrm{ppm}$ quenching of excited $\mathrm{OH}$ (see table 1) and the reduced electron temperature become relevant. Both counter the emission gain by increased $\mathrm{OH}$ density and a maximum evolves. Of course, no information on $\mathrm{OH}$ densities is given in this paper and therefore conclusions concerning $\mathrm{OH}$ densities are speculative. However, a rising $\mathrm{OH}$ density is a reasonable explanation for the formation of the observed maximum. Otherwise, it would mean that for increasing feed gas humidity up to $400 \mathrm{ppm}$ more $\mathrm{OH}$ molecules become excited than for the dry condition despite de-excitation losses by increased quenching and reduced electron temperature.

Interesting results were also found by analysing the axial dependence of the emission signals. Except for nitrogen, the highest emission intensity was always found close to the nozzle. From there on, the intensity decreases towards longer nozzle distances. Nitrogen behaves differently because no significant nitrogen density is present close to the nozzle. Hence, no nitrogen excitation can occur in this region. With a longer nozzle distance, the diffusion of ambient nitrogen into the effluent drastically increases [21,24] and a stronger emission intensity is obtained. However, since the excitation of nitrogen becomes less likely with increasing distance from the nozzle, an emission maximum is reached at an axial position of about $5.5 \mathrm{~mm}$. For larger distances the emission signal decreases monotonically despite a still increasing nitrogen density.

Analogous to ambient nitrogen ambient oxygen also diffuses into the effluent and is potentially dissociated by 
Table 1. Quenching rate coefficients for different excited species with state energies $E$, when $\mathrm{H}_{2} \mathrm{O}$ is the quenching molecule. Furthermore, the decay rates due to radiative decay and due to quenching (for a humidity concentration of $1000 \mathrm{ppm}$ ) are given.

\begin{tabular}{lllll}
\hline \multirow{2}{*}{$\begin{array}{l}\text { Excited } \\
\text { state }\end{array}$} & $\begin{array}{l}E \\
(\mathrm{eV})\end{array}$ & $\begin{array}{l}\text { Quenching rate coefficient for } \\
\mathrm{H}_{2} \mathrm{O}\left(10^{-10} \mathrm{~cm}^{3} \mathrm{~s}^{-1}\right)\end{array}$ & \multicolumn{2}{c}{ Decay rate $\left(10^{7} \mathrm{~s}^{-1}\right)$} \\
\hline $\mathrm{N}_{2}\left(C^{3} \Pi_{\mathrm{u}}, v=0\right)$ & $11.18[26]$ & $7.1 \pm 0.7[27]$ & $2.39 \pm 0.08[27]$ & $1.75 \pm 0.17$ \\
& & & $2.63[28]$ & Due to $\mathrm{H}_{2} \mathrm{O}_{\text {quenching }}{ }^{\mathrm{a}}$ \\
$\mathrm{OH}\left(A^{2} \Sigma^{+}, v=0\right)$ & $4.25[29]$ & $5.66 \pm 0.1[30]$ & $0.139[30]$ & $1.40 \pm 0.02$ \\
$\mathrm{O}\left(3 \mathrm{p}^{3} \mathrm{P}\right)$ & $10.99[31]$ & $49 \pm 3[32]$ & $2.69 \pm 0.24[32]$ & $12.1 \pm 0.74$ \\
& & $9.4 \pm 1.5[33]$ & & $2.32 \pm 0.37$ \\
$\mathrm{O}\left(3 \mathrm{p}^{5} \mathrm{P}\right)$ & $10.74[31]$ & $\mathrm{n} / \mathrm{a}$ & $2.56[34]$ & - \\
$\mathrm{Ar}\left(1 \mathrm{~s}_{5}\right)$ & $11.55[31]$ & $4.8[35]$ & Metastable & 1.19 \\
$\operatorname{Ar}\left(2 \mathrm{p}_{2}\right)$ & $13.33[31]$ & $\mathrm{n} / \mathrm{a}$ & $4.35[31]$ & - \\
\hline
\end{tabular}

${ }^{\mathrm{a}}$ Calculated for a $\mathrm{H}_{2} \mathrm{O}$ concentration of $1000 \mathrm{ppm}$.

radiation or high energetic particles. However, the highest emission intensity is found in front of the jet nozzle. This indicates that, in addition to the atomic oxygen production in the jet effluent, atomic oxygen is also produced inside the active plasma zone. Analogous to the discussion of feed gas humidity originating from the gas supply tubes (see section 3.1), it is reasonable to assume that even for the dry condition, water molecules are still present in the feed gas in a concentration between $0 \mathrm{ppm}$ and $20 \mathrm{ppm}$ (the detection limit of hygrometer). Hence, atomic oxygen is generated from water dissociation in the active plasma zone and becomes excited by electron collisions. This explains the observed emission signal of atomic oxygen in front of the jet nozzle.

OES was also used to indicate whether feed gas humidity has a larger effect on the $\mathrm{OH}$ emission than ambient air humidity. Figure 9 shows the integrated emission intensity of $\mathrm{OH}$ for the two investigated conditions. When dry feed gas and humidified shielding gas are used the axial intensity increases with distance to the nozzle. Similar to the discussion for nitrogen, the $\mathrm{OH}$ density continuously increases with distance. Since excitation is limited in the axial direction the emission profile forms a maximum. Identical to nitrogen emission, the highest emission signal was found at a distance of $5.5 \mathrm{~mm}$. In contrast, when humidified feed gas and dry shielding gas are used the emission signal decreases steadily in the axial direction and no maximum evolves. Particularly interesting is the fact that although the feed gas humidity concentration in this case is by a factor of 42 lower compared with the humidity concentration in the wet shielding gas, a higher $\mathrm{OH}$ emission signal is detected (for $z<5 \mathrm{~mm}$ ).

In conclusion, ambient air humidity influences the chemical and physical processes in the plasma effluent and must be considered especially for applications that require stable plasma conditions. In fact, much more important than controlling the ambient humidity is to consider the feed gas humidity since it affects the plasma substantially.

\subsection{Ozone net production rate depends on feed gas humidity}

In addition to other reactive species such as atomic oxygen or hydroxyl radicals, ozone $\left(\mathrm{O}_{3}\right)$ also plays a key role in plasma chemical processes. Under a condition where molecular oxygen density is significantly higher than the atomic oxygen density, which is usually the case for the effluent region of the

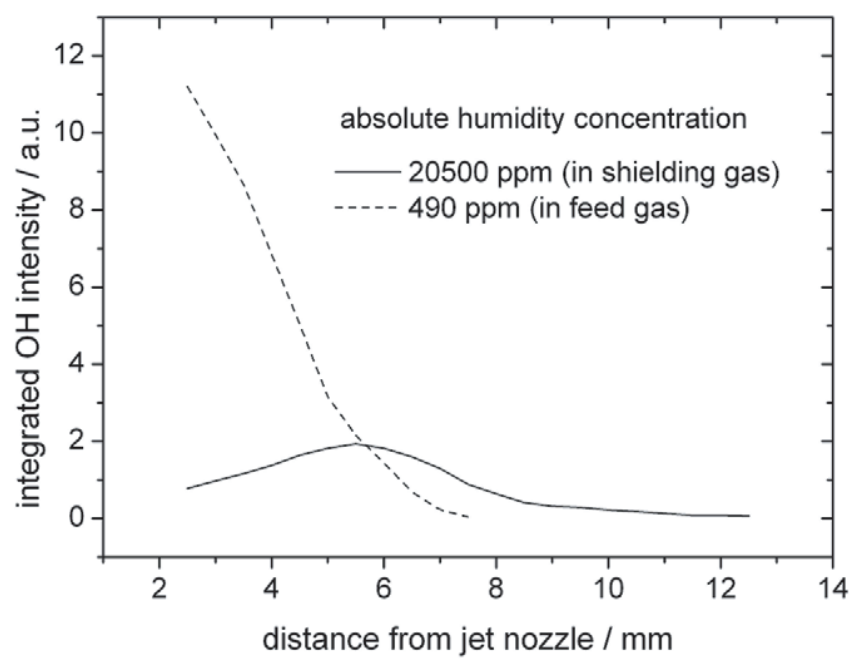

Figure 9. Comparison of the axial $\mathrm{OH}$ emission profiles for two conditions: firstly, dry shielding gas and humidified feed gas; secondly, humidified shielding gas and dry feed gas.

plasma jet, ozone can be interpreted as an indicator for atomic oxygen since it is mainly produced by the following reaction:

$$
\mathrm{O}_{2}+\mathrm{O}+M \rightarrow \mathrm{O}_{3}+M,
$$

where $M$ is an arbitrary collision partner, e.g. argon. Since the emission of excited atomic oxygen is linked to the humidity concentration in the feed gas it is reasonable to assume that the production of atomic oxygen and therefore the production of $\mathrm{O}_{3}$ are also affected by feed gas humidity changes. The $\mathrm{O}_{3}$ measurement result of the two applied absorption spectroscopic techniques (UV and IR laser absorption spectroscopy) is presented in figure 10. In order to compare both methods the ozone net production rate of the jet was calculated and plotted in this figure. Despite the different techniques remarkable agreement between both methods is ascertained. Generally, the highest $\mathrm{O}_{3}$ net production rate of $(3 \ldots 4) \times 10^{17} \mathrm{~s}^{-1}$ is found for the driest condition. With increasing humidity concentration up to $200 \mathrm{ppm}$ a steep decrease in ozone net production rate is obtained. For humidity concentrations larger than $200 \mathrm{ppm}$ a decrease in ozone net production is still observed but is not as strong as for lower humidity concentrations. For more than $800 \mathrm{ppm}$ the $\mathrm{O}_{3}$ net production rate drops below $1 \times 10^{17} \mathrm{~s}^{-1}$. A further 


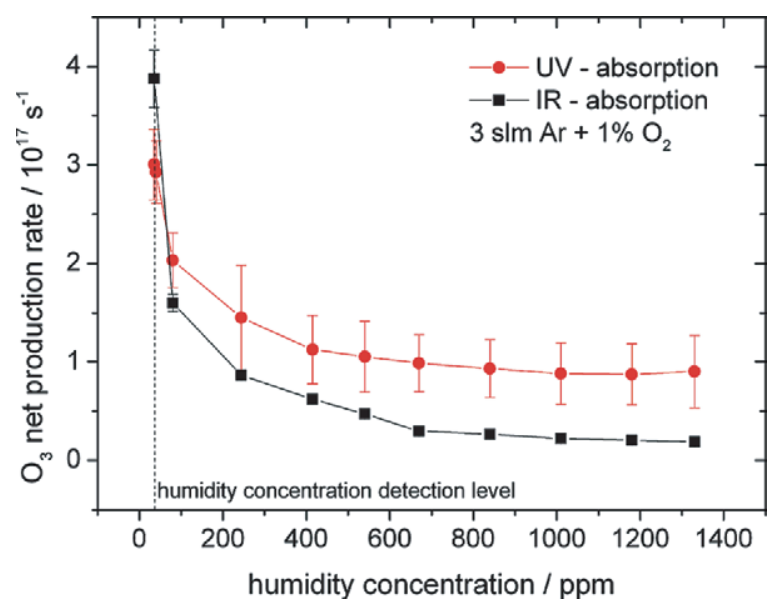

Figure 10. Ozone net production rate in dependence on the feed gas humidity concentration. The measurements were made with UV and IR absorption techniques.

humidity increase does not change the $\mathrm{O}_{3}$ net production rate significantly.

The decrease in ozone net production with increasing feed gas humidity means that a higher humidity level either inhibits the production and/or favours the destruction of ozone. Without a plasma chemical model or an $\mathrm{O}$ atom density measurement it is difficult to disentangle both mechanisms. However, since ozone is mainly formed by one single reaction (equation (1)), atomic oxygen acts as a bottleneck for the ozone production. If the atomic oxygen density is affected by the feed gas humidity, an increase in feed gas humidity will consequently influence the $\mathrm{O}_{3}$ formation as well. A possible mechanism for the reduction of excited atomic oxygen density by water molecules is given by the following reactions [39]:

$$
\begin{gathered}
\mathrm{O}\left({ }^{1} \mathrm{D}\right)+\mathrm{H}_{2} \mathrm{O} \rightarrow \mathrm{OH}+\mathrm{OH}, \\
\mathrm{O}\left({ }^{1} \mathrm{~S}\right)+\mathrm{H}_{2} \mathrm{O} \rightarrow \mathrm{OH}+\mathrm{OH} .
\end{gathered}
$$

Both reduce the amount of atomic oxygen available for reaction (1). This results in a lower ozone production with increasing water molecule admixture. However, not only a lower atomic oxygen concentration but also different humidity-depending destruction mechanisms reduce the ozone concentration and lead to the observed ozone behaviour of figure 10. One candidate is the reaction of ozone with $\mathrm{OH}$ in a cyclic process [40]:

$$
\begin{gathered}
\mathrm{O}_{3}+\mathrm{OH} \rightarrow \mathrm{HO}_{2}+\mathrm{O}_{2} \\
\mathrm{O}_{3}+\mathrm{HO}_{2} \rightarrow 2 \mathrm{O}_{2}+\mathrm{OH},
\end{gathered}
$$

where a single $\mathrm{OH}$ molecule is able to destroy more than one ozone molecule. According to the discussion in section 3.2, the $\mathrm{OH}$ density most likely increases with humidity in order to explain the observed maximum in the $\mathrm{OH}$ emission signal. Hence, the ozone destruction cycle of equations (4) and (5) becomes prominent when the water concentration in the feed gas rises. Furthermore, reactions with hydrogen also lead to ozone decomposition [40]:

$$
\mathrm{O}_{3}+\mathrm{H} \rightarrow \mathrm{O}_{2}+\mathrm{OH}
$$

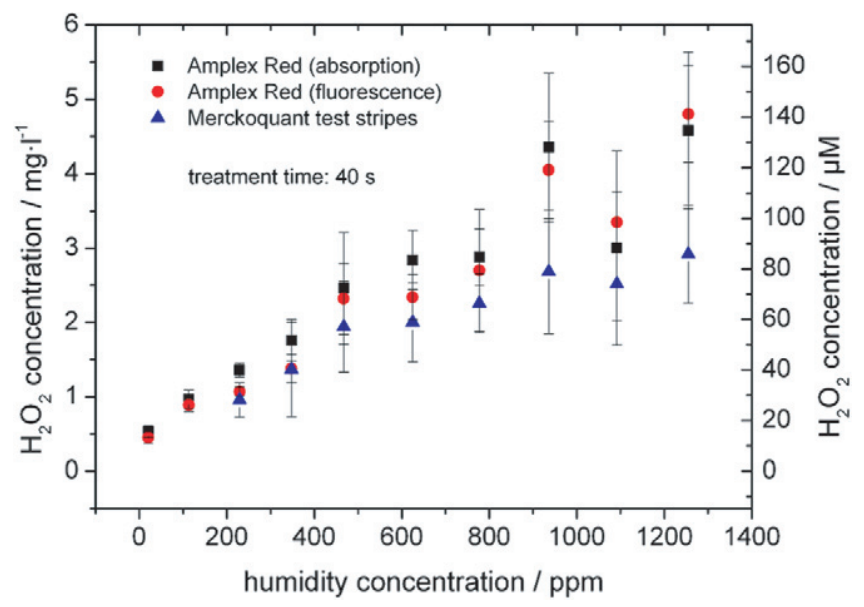

Figure 11. $\mathrm{H}_{2} \mathrm{O}_{2}$ concentration in a plasma-treated liquid increases with feed gas humidity. Merckoquant stripes and the Amplex Red assay were utilized for $\mathrm{H}_{2} \mathrm{O}_{2}$ detection.

Since hydrogen can only originate from water dissociation an increase in feed gas humidity will favour the generation of atomic hydrogen, which in turn will contribute to the ozone decomposition.

\section{4. $\mathrm{H}_{2} \mathrm{O}_{2}$ concentration in RPMI increases with feed gas humidity}

The increase in feed gas humidity not only changes the optical emission spectrum and the ozone production of the jet but also affects the plasma-treated liquid. In figure 11, the $\mathrm{H}_{2} \mathrm{O}_{2}$ concentration is displayed for different feed gas humidity concentrations. The results of both utilized methods, namely the Merckoquant stripes and the Amplex Red assay, show remarkable agreement and indicate an increase in $\mathrm{H}_{2} \mathrm{O}_{2}$ concentration in the liquid with increasing feed gas humidity. For the highest investigated humidity setting a $\mathrm{H}_{2} \mathrm{O}_{2}$ concentration of almost $4 \mathrm{mg} \mathrm{l}^{-1}$ is measured after $40 \mathrm{~s}$ plasma exposure. Under dry gas conditions an $\mathrm{H}_{2} \mathrm{O}_{2}$ concentration of around $0.5 \mathrm{mg}^{-1}$ is still measured with the Amplex Red assay. Owing to the limited sensitivity no reliable data are obtained from the test stripes for this condition. For both humidity settings (driest and most humid), the $\mathrm{H}_{2} \mathrm{O}_{2}$ production rate is calculated assuming a linear increase in the $\mathrm{H}_{2} \mathrm{O}_{2}$ concentration with treatment time. Production rates of $1.8 \times 10^{-3} \mathrm{~g} \mathrm{~h}^{-1}$ for the highest humidity setting and $2.0 \times 10^{-4} \mathrm{~g} \mathrm{~h}^{-1}$ for the driest feed gas condition are obtained. A similar value of $3 \times 10^{-4} \mathrm{~g} \mathrm{~h}^{-1}$ was obtained by Ikawa et al using a plasma jet driven in dry helium [41].

Different mechanisms are known on how hydrogen peroxide is generated in liquids $[42,43]$. A basic pathway is the recombination of hydroxyl radicals in the liquid. These $\mathrm{OH}$ molecules are either generated directly inside the liquid by radiation, excited species or electrons from the plasma or are primarily produced in the plasma phase and recombine afterwards on the liquid surface to $\mathrm{H}_{2} \mathrm{O}_{2}$. Another possibility is that $\mathrm{H}_{2} \mathrm{O}_{2}$ is produced in the gas phase and simply dissolved in the liquid. In that case the $\mathrm{H}_{2} \mathrm{O}_{2}$ concentration in the gas phase must increase with increasing humidity level. Support 


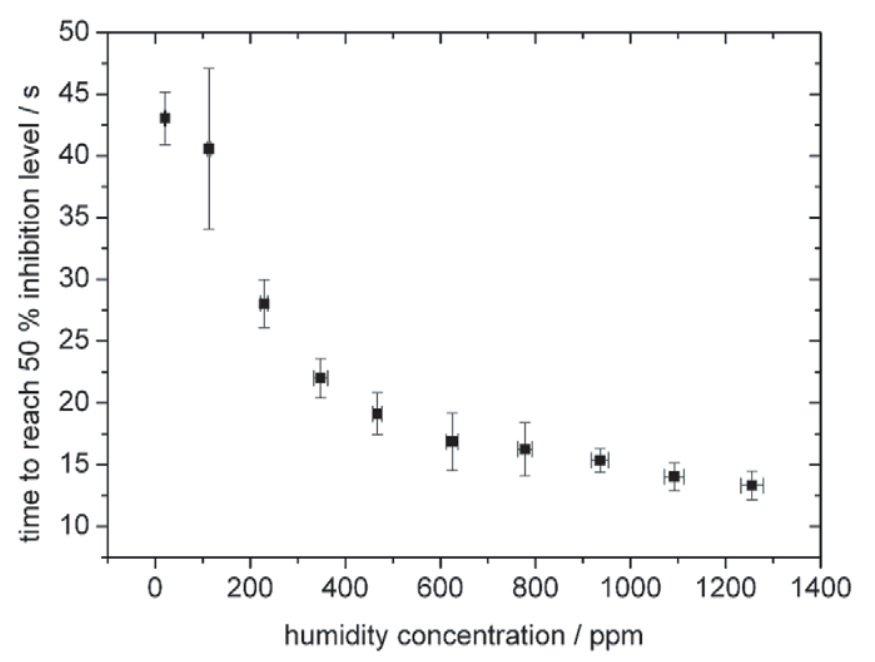

Figure 12. Cell viability determined by resazurin assay in dependence on the feed gas humidity concentration. The cells were treated indirectly.

for this theory is found in the model results of Liu et al where an increase in $\mathrm{H}_{2} \mathrm{O}_{2}$ with humidity is predicted [16]. However, this model is computed for helium, whereas in this work an argon plasma jet was used. Measurements of $\mathrm{H}_{2} \mathrm{O}_{2}$ in the gas phase are necessary and planned for future work in order to identify a correlation between $\mathrm{H}_{2} \mathrm{O}_{2}$ in the gas and liquid phases.

\subsection{Cell viability after indirect plasma treatment is impeded with higher humidity}

In figure 12, the influence of different feed gas humidity settings on the viability of human skin cells is presented. Cell viability detection utilized in this study relies on a cellular supply of reduction equivalents to reduce a tracer compound (resazurin, containing an N-oxide) enzymatically yielding a highly fluorescent reporter dye (resofurin). Hence, cells need to be both living and metabolically active to be detected, which allows the conclusion on their actual viability rather than their number only. Cell viability and cell division rates strongly depend on the general condition of the cells, which will be influenced by many factors, such as nutrition, availability of oxygen, and also on harming influences such as oxidative stress. Under this condition, cells face imbalance between reactive oxygen species (ROS) concentration and their ability to detoxify the reactive intermediates or to repair the resulting damage. Some ROS or their degradation products are known to be highly reactive with biomolecules such as proteins, lipids and DNA. In addition to a direct random modification of these molecules by covalent implementation of functional groups or altering their redox status, indirect effects can be transmitted via cellular redox sensors such as the different peroxiredoxins [44]. In turn, these molecules activate cellular antioxidant defence mechanisms, which allow the cells to withstand a certain ROS excess. From figure 12 it is evident that the plasma generated by the feed gas with a content of humidity affects the cell viability even more than the plasma created from the dry feed gas. Considering the findings of the $\mathrm{H}_{2} \mathrm{O}_{2}$ concentration measurements of section 3.4 a correlation between cell viability and $\mathrm{H}_{2} \mathrm{O}_{2}$ concentration becomes obvious. This means when the $\mathrm{H}_{2} \mathrm{O}_{2}$ concentration is low, the cell viability is high. With increasing $\mathrm{H}_{2} \mathrm{O}_{2}$ concentration a decrease in cell viability is also observed. In conclusion, by applying the plasma source in our eukaryotic cell model the cells were exposed to ROS and, hence, to oxidative stress, which exceed the cells' capacity for detoxification and repair. Although $\mathrm{H}_{2} \mathrm{O}_{2}$ plays an important role in the oxidative stress that affects the cell viability, other reactive species such as $\mathrm{OH}$ or $\mathrm{O}_{2}^{-}$might also be involved in the observed effects. Cell viability could be influenced by mechanical stress or electric fields derived from the plasma source $[45,46]$. Since indirect plasma treatment was applied, these and other stress factors such as UV radiation were excluded for our experimental conditions.

\section{Conclusion}

In this paper, the significant influence of feed gas humidity introduced into an atmospheric-pressure argon plasma jet is demonstrated on the axially resolved optical emission spectrum of the jet effluent, the generation of hydrogen peroxide in a plasma-treated cell growth medium and on human skin cells charged with this treated medium. Optical emission spectroscopy reveals a strong dependence of present excited plasma species such as hydroxyl radicals, molecular nitrogen, argon and atomic oxygen on the feed gas humidity. Furthermore, it was demonstrated by this spectroscopic method that small feed gas humidity concentrations (below $1000 \mathrm{ppm}$ ) have a much larger effect on $\mathrm{OH}$ emission than high ambient humidity concentrations. From this finding it is concluded that whenever humid feed gas is applied, ambient humidity can be neglected for processes inside the effluent region. However, when the feed gas is dry, ambient humidity becomes important and must be considered in such a situation. The question whether used feed gas is dry or humid is complicated by the fact that polymeric supply tubes have a major contribution to the feed gas humidity. It is shown that a vast amount of water vapour diffuses through PUR tube walls and hence increases the feed gas humidity. Compared with metal tubes a ten times higher concentration was found for the polymeric tubes. Depending on the length of the feed gas tubes, a constantly changing feed gas humidity prevents stable plasma conditions for up to several hours.

Furthermore, plasma treatment of the liquid cell growth medium with increasing feed gas humidity leads to an almost linear increase in $\mathrm{H}_{2} \mathrm{O}_{2}$ concentration in the liquid. When human skin cells get challenged with this medium a strong correlation between cell viability and $\mathrm{H}_{2} \mathrm{O}_{2}$ concentration is revealed, indicative of an oxidative stress response.

\section{Acknowledgments}

This work is funded by the German Federal Ministry of Education and Research (Grant Nos 03Z2DN11 and 03Z2DN12). The authors gratefully acknowledge the precious work of Liane Kantz, Steffen Hahn, Sarah Kupsch, Sebastian Schlegel, Mattis Hänel and Sven Bordewick. 


\section{References}

[1] Sarra-Bournet C, Turgeon S, Mantovani D and Laroche G 2006 A study of atmospheric pressure plasma discharges for surface functionalization of PTFE used in biomedical applications J. Phys. D: Appl. Phys. 39 3461-9

[2] Bhoj A N and Kushner M J 2005 Plasma-polymer interactions in a dielectric barrier discharge IEEE Trans. Plasma Sci. 33 250-1

[3] Fricke K, Reuter S, Schroder D, Schulz-von der Gathen V, Weltmann K-D and von Woedtke T 2012 Investigation of surface etching of poly(ether ether ketone) by atmospheric-pressure plasmas IEEE Trans. Plasma Sci. 40 2900-11

[4] Rombola G, Parisi F, Pavan C and Dapra D 2006 On-line atmospheric pressure plasma (APP) treatment of polypropylene fabrics Czech. J. Phys. 56 B1021-8

[5] Yonson S, Coulombe S, Leveille V and Leask R L 2006 Cell treatment and surface functionalization using a miniature atmospheric pressure glow discharge plasma torch J. Phys. D: Appl. Phys. 39 3508-13

[6] Moreau E 2007 Air flow control by non-thermal plasma actuators J. Phys. D: Appl. Phys. 40 605-36

[7] Paulussen S, Rego R, Goossens O, Vangeneugden D and Rose K 2005 Physical and chemical properties of hybrid barrier coatings obtained in an atmospheric pressure dielectric barrier discharge J. Phys. D: Appl. Phys. 38 568-75

[8] Kucerova Z, Zajickova L, Jasek O, Elias M, Ficek R, Vrba R, Matejka F, Matejkova J and Bursik J 2006 Carbon nanotubes synthesized by plasma enhanced CVD: preparation for measurements of their electrical properties Czech. J. Phys. 56 B1244-9

[9] Ehlbeck J, Schnabel U, Polak M, Winter J, von Woedtke T, Brandenburg R, von dem Hagen T and Weltmann K D 2011 Low temperature atmospheric pressure plasma sources for microbial decontamination J. Phys. D: Appl. Phys. 44013002

[10] Kong M G, Kroesen G, Morfill G, Nosenko T, Shimizu T, van Dijk J and Zimmermann J L 2009 Plasma medicine: an introductory review New J. Phys. 11115012

[11] Weltmann K D, Polak M, Masur K, von Woedtke T, Winter J and Reuter S 2012 Plasma processes and plasma sources in medicine Contrib. Plasma Phys. 52 644-54

[12] Marchal F, Robert H, Merbahi N, Fontagne-Faucher C, Yousfi M, Romain C E, Eichwald O, Rondel C and Gabriel B 2012 Inactivation of Gram-positive biofilms by low-temperature plasma jet at atmospheric pressure J. Phys. D: Appl. Phys. 45345202

[13] Fridman A 2008 Plasma Chemistry (Cambridge: Cambridge University Press)

[14] Sakiyama Y, Graves D B, Chang H W, Shimizu T and Morfill G E 2012 Plasma chemistry model of surface microdischarge in humid air and dynamics of reactive neutral species J. Phys. D: Appl. Phys. 45425201

[15] Murakami T, Niemi K, Gans T, O'Connell D and Graham W G 2013 Chemical kinetics and reactive species in atmospheric pressure helium-oxygen plasmas with humid-air impurities Plasma Sources Sci. Technol. 22015003

[16] Liu D X, Bruggeman P, Iza F, Rong M Z and Kong M G 2010 Global model of low-temperature atmospheric-pressure $\mathrm{He}$ $+\mathrm{H}_{2} \mathrm{O}$ plasmas Plasma Sources Sci. Technol. 19025018

[17] Kirkpatrick M J, Dodet B and Odic E 2007 Atmospheric pressure humid argon DBD plasma for the application of sterilization-measurement and simulation of hydrogen, oxygen, and hydrogen peroxide formation Int. J. Plasma Environ. Sci. Technol. 1 96-101

[18] Hähnel M, von Woedtke T and Weltmann K D 2010 Influence of the air humidity on the reduction of bacillus spores in a defined environment at atmospheric pressure using a dielectric barrier surface discharge Plasma Process. Polym. 7 244-9

[19] Weltmann K D, Kindel E, von Woedtke T, Hahnel M, Stieber M and Brandenburg R 2010 Atmospheric-pressure plasma sources: prospective tools for plasma medicine Pure Appl. Chem. 82 1223-37

[20] Reuter S, Winter J, Iseni S, Peters S, Schmidt-Bleker A, Dünnbier M, Schäfer J, Foest R and Weltmann K D 2012 Detection of ozone in a $\mathrm{MHz}$ argon plasma bullet jet Plasma Sources Sci. Technol. 21034015

[21] Reuter S, Winter J, Schmidt-Bleker A, Tresp H, Hammer M U and Weltmann K D 2012 Controlling the ambient air affected reactive species composition in the effluent of an argon plasma jet IEEE Trans. Plasma Sci. 40 2788-94

[22] Winter J, Dünnbier M, Schmidt-Bleker A, Meshchanov A, Reuter S and Weltmann K D 2012 Aspects of UV-absorption spectroscopy on ozone in effluents of plasma jets operated in air J. Phys. D: Appl. Phys. 45385201

[23] Zhu A P, Romero R and Petty H R 2010 A sensitive fluorimetric assay for pyruvate Anal. Biochem. 396 146-51

[24] Reuter S, Tresp H, Wende K, Hammer M U, Winter J, Masur K, Schmidt-Bleker A and Weltmann K D 2012 From RONS to ROS: tailoring plasma jet treatment of skin cells IEEE Trans. Plasma Sci. 40 2986-93

[25] Bruggeman P, Iza F, Guns P, Lauwers D, Kong M G, Gonzalvo Y A, Leys C and Schram D C 2010 Electronic quenching of $\mathrm{OH}(\mathrm{A})$ by water in atmospheric pressure plasmas and its influence on the gas temperature determination by $\mathrm{OH}(A-X)$ emission Plasma Sources $S c i$. Technol. 19015016

[26] Benesch W, Vanderslice J T, Tilford S G and Wilkinson P G 1965 Potential curves for observed states of $\mathrm{N}_{2}$ below $11 \mathrm{eV}$ Astrophys. J. 1421227

[27] Morozov A, Krucken R, Wieser J and Ulrich A 2005 Gas kinetic studies using a table-top set-up with electron beam excitation: quenching of molecular nitrogen emission by water vapour Eur. Phys. J. D 33 207-11

[28] Jeunehomme M and Duncan A B F 1964 Lifetime measurements of some excited states of nitrogen nitric oxide + formaldehyde J. Chem. Phys. 411692

[29] Fallon R J, Vanderslice J T and Tobias I 1961 Potential energy curves for $\mathrm{OH} J$. Chem. Phys. 34167

[30] Mcdermid I S and Laudenslager J B 1982 Radiative lifetimes and quenching rate coefficients for directly excited rotational levels of $\mathrm{OH}\left(A^{2} \Sigma^{+}, v^{\prime}=0\right) J$. Chem. Phys. 76 1824-31

[31] Kelleher D E, Martin W C, Wiese W L, Sugar J, Fuhr J R, Olsen K, Musgrove A, Mohr P J, Reader J and Dalton G R 1999 The new NIST Atomic Spectra Database Phys. Scr. T83 158-61

[32] Meier U, Kohse-Höinghaus K and Just T 1986 H-atom and O-atom detection for combustion applications-study of quenching and laser photolysis effects Chem. Phys. Lett. $126567-73$

[33] Quickenden T I, Trotman S M, Irvin J A and Sangster D F $1979 \mathrm{H}_{2} \mathrm{O}$ quenching of the transitions $\mathrm{H}(n=3 \rightarrow n=2)$ and $\mathrm{O}\left(3 \mathrm{p}^{3} \mathrm{P} \rightarrow 3 \mathrm{~s}^{3} \mathrm{~S}^{0}\right)$ in pulse radiolytically excited water-vapor J. Chem. Phys. 71 497-501

[34] Belikov A E, Kusnetsov O V and Sharafutdinov R G 1995 The rate of collisional quenching of $\mathrm{N}_{2} \mathrm{O}^{+}\left(B^{2} \Sigma\right), \mathrm{N}_{2}^{+}\left(B^{2} \Sigma\right)$, $\mathrm{O}_{2}^{+}\left(b^{4} \Sigma\right), \mathrm{O}^{+}(3 d), \mathrm{O}(3 p), \operatorname{Ar}^{+}\left(4 p^{\prime}\right), \operatorname{Ar}\left(4 p, 4 p^{\prime}\right)$ at the temperature $\leqslant 200 \mathrm{~K}$ J. Chem. Phys. 102 2792-801

[35] Velazco J E, Kolts J H and Setser D W 1978 Rate constants and quenching mechanisms for metastable states of argon, krypton, and xenon J. Chem. Phys. 69 4357-73 
This is the Accepted Manuscript version -post-print- of an article accepted for publication in Journal of Physics D: Applied Physics. This article may be downloaded for personal use only. Any other use requires prior permission of the authors and IOP Publishing. This article may be found at doi:10.1088/0022-3727/46/29/295401.

IOP Publishing is not responsible for any errors or omissions in this version of the manuscript or any version derived from it

[36] Nikiforov A Y, Sarani A and Leys C 2011 The influence of water vapor content on electrical and spectral properties of an atmospheric pressure plasma jet Plasma Sources Sci. Technol. 20015014

[37] Sands B L, Leiweke R J and Ganguly B N 2010 Spatiotemporally resolved $\operatorname{Ar}(1 \mathrm{~s}(5))$ metastable measurements in a streamer-like $\mathrm{He} / \mathrm{Ar}$ atmospheric pressure plasma jet J. Phys. D: Appl. Phys. 43282001

[38] Bussiahn R, Kindel E, Lange H and Weltmann K D 2010 Spatially and temporally resolved measurements of argon metastable atoms in the effluent of a cold atmospheric pressure plasma jet J. Phys. D: Appl. Phys. 43165201

[39] Herron J T and Green D S 2001 Chemical kinetics database and predictive schemes for nonthermal humid air plasma chemistry: II. Neutral species reactions Plasma Chem. Plasma Process. 21 459-81

[40] Skalny J D, Orszagh J, Matejcik S and Mason N J 2008 Ozone generation in positive and negative corona discharge fed by humid oxygen and carbon dioxide Phys. Scr. T131 014012

[41] Ikawa S, Kitano K and Hamaguchi S 2010 Effects of $\mathrm{pH}$ on bacterial inactivation in aqueous solutions due to low-temperature atmospheric pressure plasma application Plasma Process. Polym. 7 33-42

[42] Locke B R and Shih K Y 2011 Review of the methods to form hydrogen peroxide in electrical discharge plasma with liquid water Plasma Sources Sci. Technol. 20034006

[43] Oehmigen K, Winter J, Hähnel M, Wilke C, Brandenburg R, Weltmann K D and von Woedtke T 2011 Estimation of possible mechanisms of Escherichia coli inactivation by plasma treated sodium chloride solution Plasma Process. Polym. 8 904-13

[44] Cox A G, Winterbourn C C and Hampton M B 2010 Mitochondrial peroxiredoxin involvement in antioxidant defence and redox signalling Biochem. J. 425 313-25

[45] Legazpi L, Laca A and Diaz M 2009 Kinetic analysis of hybridoma cells viability under mechanical shear stress with and without serum protection Bioprocess. Biosyst. Eng. 32 717-22

[46] Yano M, Abe K, Akiyama H and Katsuki S 2012 Enhancement of proliferation activity of mammalian cells by intense burst sinusoidal electric fields IEEE Trans. Dielectr. Electr. Insul. $19331-6$ 